\title{
Playing Activities Improve Manipulative Skills: a Literature Review
}

\author{
Palupi Ardanari, Edy Mintarto, Abdul Rahman Syam Tuasikal, Suroto \\ Universitas Negeri Surabaya \\ *ardanaripalupi@gmail.com
}

\begin{abstract}
Playing activities provide positive stimulation for manipulative movement skills of children aged 6-12 years. Playing activities, including physical activities that have the opportunity to reduce the risk of obesity in children aged 6-12 years. Playing activity interventions in obese children are recommended on basic motion skills and motion coordination. The purpose of the review in this journal is to show the contribution of playing activities to children's manipulative movement skills. The review method that used was a journal search system with keywords manipulative motion skills on Google. 12 national journals have been reviewed based on playing activity models, methods, samples, and research results. The conclusion of the review results showed that variations in playing activities undertaken by children positively contribute to the manipulative movement skills of children in living their daily lives.
\end{abstract}

Keywords: Playing Activities, Children, Manipulative Skills 


\section{STRADA Jurnal Ilmiah Kesehatan}

DOI: $10.30994 /$ sjik.v9i2.294

ISSN: 2252-3847 (print); 2614-350X (online)

Vol.9 No.2 November 2020 Page.374-380

\section{BACKGROUND}

Manipulative skills are the coordination of some motion skills in the members of human body (Mirawati, 2017). The manipulative motion of children starts from motor and locomotor skills. The development of manipulative skills gives children confidence and ease in living their daily lives. Sample observations with the reason that the sample has less manipulative skills are the basis of some previous studies to carry out research (Hendra, 2019; Dlis, 2018; Yasin, 2018; Arifin, 2017; Sulistyani, 2016; Nugroho, 2016; Suyantini, 2013).

Poor manipulative skill is one of the impacts arising from uncontrolled physical growth (Obesity). Obesity is an increase in body weight caused by excessive increase in body fat tissue in individuals (Sjarif, 2002). Research Hadi (2015) found that the frequency of obesity in children by $10.8 \%$. The distribution of obesity is higher in male students by $13 \%$ with the incidence of obesity is mostly found in children aged over 9 years which is $14.7 \%$. While the Suryamulyawan study (2019) found that $17.2 \%$ of obese children, $18.2 \%$ overweight children, $54.6 \%$ normal BMI children, and $10.0 \%$ underweight children of 1003 students. While the characteristics of obese children are obtained: $62.2 \%$ of obese children aged $<9$ years with $73.4 \%$ of obese children are boys.

Intervention solution to improve manipulative skills and reduce cases of obesity in children is done by providing physical activity to children using playing methods (Han, 2017; Arifin, 2017). The playing method fosters motivation and enthusiasm for activities carried out because it is fun and exciting (Widodo, 2015). Based on the description above, the purpose of journal review is to provide literacy of knowledge related to playing activities that are recommended in improving the ability of manipulative movement in children aged 6-12 years.

\section{METHOD}

The review method used the journal search system method with the keywords manipulative motion skills on the "Google scholar" search engine. Journals that are in accordance with these keywords are reviewed based on the intervention model, method, sample, and research results.

\section{RESULT}

The review method with search system keywords of manipulative movement skills on the "Google" search engine resulted in 12 national journals to be reviewed. The following are the results of the review based on the intervention model, method, sample, and research results.

1. - Author: Jhony Hendra and Ghazali Indra Putra (2019)

- Intervention Model: Sports games on the aspects of throwing, catching, kicking, and dribbling

- Method: Qualitative descriptive (case study)

- Sample: Population in TK Negeri Pembina Muara Bungo

- Result: Efforts to develop basic manipulative movements are carried out using tools, the process of development through sports activities by giving directions and examples to children.

2. - Author: Firmasyah Dlis (2018)

- Intervention Model: Traditional play games, namely: galaxing, bentengan, ball throwing groups, fishing, ular naga and ketok lele 


\section{STRADA Jurnal Ilmiah Kesehatan}

DOI: $10.30994 /$ sjik.v9i2.294

ISSN: 2252-3847 (print); 2614-350X (online)

- Method: Research and Development with pretest -postest design

- Sample: 20 elementary school students

- Result: Manipulative exercises based on play games develop children's kinesthetic abilities into marvelous categories.

3. - Author: Muh. Yasin (2018)

- Intervention Model: Kicking ball modification

- Method: pretest-postest design, research instrumental using shooting test

- Sample: 10 children with mental retardation

- Result: There is an increase in the value of the results of the shooting test after the game modification intervention kicking the ball.

4. - Author: Muhammad Juniansyah Eko (2018)

- Intervention Model: Development of small game models

- Method: Research and Development with pretest -postest design

- Sample: 40 senior school students

- Result: The manipulative basic motion learning model based on small games provides an increase in manipulative abilities based on testing the results of the pretest-posttest data with a significant difference between before and after the treatment of the model.

5. - Author: Lesmana Nugraha, Agus Mahendra, Indra Herdiyana (2018)

- Intervention Model: Movement education model through movement analysis framework

- Method: Classroom action research

- Sample: 23 students of fifth grade

- Result: The application of the motion education model by involving a movement analysis framework can improve the manipulative basic patterns of movement of the fifth grade students

6. - Author: Mirawati dan Eva Rahmawati (2017)

- Intervention Model: Modified game

- Method: article review

- Sample: -

- Result: Modified games provide positive stimulation for the increase in manipulative movement abilities which include the ability to throw, catch, kick, roll, and bounce the ball.

7. - Author: Galih Dwi Pradipta (2017)

- Intervention Model: Gymnastic

- Method: Journal review

- Sample: -

- Result: Characteristic and structure of gymnastic movements is a physical activity that is recommended for the development of children's movement skills and physical quality. Gymnastics contains locomotor movements that are considered capable of improving aspects of strength, speed, power, endurance, agility, and balance in children. Linked to non locomotor motion exercises can improve aspects of strength, flexibility, and static balance. Associated with manipulative motion exercises can stimulate the ability to coordinate and stimulate processing at the center of children's awareness. 


\section{STRADA Jurnal Ilmiah Kesehatan}

DOI: $10.30994 /$ sjik.v9i2.294

8. - Author: Muhammad Zainal Arifin (2017)

- Intervention Model: Modified ball throwing game

- Method: pretest - postets with motor fitnes test instrument

- Sample: 14 students with mental retardation

- Result: Modifications to the game of catching the ball improve the coordination of manipulative motion.

9. - Author: Arif Hidayat (2017)

- Intervention Model: Model "kera panjat" game

- Method: classroom action research

- Sample: 30 students. 12 girls 18 boys

- Result: The application of "kera panjat" game method increases locomotor motion $70 \%$, non locomotoric $54 \%$, and manipulative $83.3 \%$.

10. - Author: Budi Sulistyani (2016)

- Model Intervention: dribble

- Method: Qualitative and quantitative description

- Sample: 19 children of Kindergarten A

- Result: Increasing the ability of manipulative movement of children in the pre-action period until the second cycle is $56.54 \%$, then $80.55 \%$, then $98.07 \%$.

11. - Author: Dedy Agung Nugroho, Agus Kristyanto, Sapta Kunta Purnama (2016)

- Intervention Model: Throw and catch the ball

- Method: Classroom action research

- Sample: 4 deaf students of third grade

- Result: The application of visual media enhances the manipulative learning outcomes of throwing and catching balls.

12. - Author: Iis Suyantini (2013)

- Intervention: Ball relay race game

- Method : Quantitative descriptive

- Sample: 20 children aged 5-6 years old

- Result: Relay race ball game has a big influence on improving the manipulative movement skills of children, especially in the ability to bounce the ball to the floor, throw a ball quickly, and catch the ball properly.

\section{DISCUSSION}

The purpose of a journal review is to provide a literacy of knowledge about manipulative skills, on what aspects, who, when, how, why manipulative skills are reviewed. The review process involves research journals that have carried out scientific research on manipulative skills. Based on the results of 12 journals review, it is recommended a game model to develop children's manipulative skills. Then to measure the increase in manipulative skills, the method used is the class action method to pre- test and post-test design. This indicates that most of the research samples that have been observed before being given an intervention have low manipulative skills, so that they are given an intervention through a game model. Then the study sample came from elementary school age. This indicates that manipulative skills are basic learning in motion must be mastered by elementary school age children. The results showed that the intervention of 


\section{STRADA Jurnal Ilmiah Kesehatan}

DOI: $10.30994 /$ sjik.v9i2.294

ISSN: 2252-3847 (print); 2614-350X (online)

Vol.9 No.2 November 2020 Page.374-380

the game model increases the manipulative skills of elementary school-aged children. These results provide positive recommendations by implementing repetitive playing activities that can improve manipulative skills.

The recommended game model is the core of manipulative movements such as throwing, catching, dribbling and kicking. This is in accordance with the opinion of Samsudin (2005) said that manipulative movements can be described in play activities such as rolling the ball, throwing, catching, kicking, receiving and controlling the ball, hitting, and reflecting the ball. Hendra's research (2019) showed that sports game models utilize sport infrastructure such as large areas, balls, cones and goalposts. In addition, the positive stimulus model of the game for manipulative development of children is also influenced by the allocation of time for children in playing activities in a week (Dlis, 2018). The method of learning motion with game models has educational and recreational functions so as to enhance students' learning skills and motivation with enthusiasm and pleasure (Hendra, 2019). The game model in children also contains locomotor and non locomotor motion elements, so it helps the development of manipulative motion (Julianur, 2017).

The results of the review indicate that the play activities carried out are supported by the existence of a ball with a playing model of kicking and throwing catches. Playing activities with kicking starts with dribbling then requires coordination of several movements, such as ankle movements, instep, and adjusting foot movements when touching the ball (Yasin, 2018). Playing activities by throwing and catching the ball can be done independently or in pairs (Arifin, 2017). By involving several movements in one comprehensive movement such as the throwing and catching of the ball which requires coordination of hand and eye movements when the ball is thrown or captured, giving rise to increased manipulative skills. The coordination of several movements is part of the concept of motion which includes: body concepts, effort concepts, spatial concepts, and relationship concepts (Nugraha, 2018). The concept of motion in question is a model of motion education by involving 5 evaluation cycles, so that it can reflect which parts must be improved (Mahendra, 2017).

The concept of manipulative motion skills is related to the skill of manipulating certain objects through the coordination of hands, feet and other limbs (Mirawati, 2017). There are two classifications of manipulative skills, namely receptive and propulsive. Receptive skills are the skills to receive an object, while the propulsive skill is a movement that has the characteristic of exerting force or strength on an object (Samsudin, 2005). Receptive and propulsive skills in playing activity model most often used are game models that use ball media. With the media of ball, a modification model of playing activity can be developed in the coordination of hand or foot movements. The game modification activity model can be done by making scores easily obtained, making movements that are easy to do, limiting the number of players so that each child has the opportunity to play, creating small groups, and the need for a competition system to motivate children to be active and passionate about playing (Mirawati, 2017).

The development of manipulative skills is aimed at elementary school age children, aged between 6-12 years old to help the process of perfecting the ability of movement. The development of manipulative skills in accordance with the model of playing activity is very much in accordance with the characteristics of children aged 6-12 years who like to play, actively move, and do activities in groups (Alim, 2009). Based on these characteristics, the research method of the results of the review shows that the method taken is pre-test/post-test with the type of classroom action research. This indicates that 


\section{STRADA Jurnal Ilmiah Kesehatan}

DOI: $10.30994 /$ sjik.v9i2.294

ISSN: 2252-3847 (print); 2614-350X (online)

Vol.9 No.2 November 2020 Page.374-380

intervention with playing activities can be seen with the existence of playing activities that are carried out repeatedly. Arifin's research (2017) showed that the intervention to modify the game of throwing the ball which carried out for 6 weeks gives a change in the ability to coordinate manipulative motion in mild retarded children. This is directly proportional to the results of research from the review journals which show that manipulative model games greatly contribute positively in increasing manipulative skills in children aged 6-12 years with activities that are carried out repeatedly.

Han's research (2017) recommended playing activities by developing children's basic movements by involving elements of coordination and balance. The study provides interventions with play activities that involve physical abilities, balance and coordination of children in overweight and obese children. The results showed that the intervention of playing activities involving physical abilities, balance, and coordination of children succeeded in increasing the skills and coordination of movement in obese and overweight children.

\section{CONCLUSION}

The results and discussion of the review in the journal above shows that playing activities undertaken by children aged 6-12 years contribute positively to manipulative skills making it easier for children to live their daily lives.

\section{REFERENCES}

Alim, Abdul. 2009. Permainan Mini Tenis untuk Pembelajaran Pendidikan Jasmani Olahraga dan Kesehatan Siswa di Sekolah Dasar. JPJI. Vol. 6. No.2

Arifin, MZ. 2017. Pengaruh Modifikasi Permainan Lempar Tangkap Bola Terhadap Koordinasi Gerak Manipulatif Anak Tunagrahita Ringan Siswa Smplb-C Alpha Kumara Wardhana II Surabaya. Jurnal Kesehatan Olahraga Vol. 07 NO. 3 Edisi Maret 2017 hal 35 - 39

Dlis, Firmansyah. 2018. Model Gerak Dasar Manipulatif Berbasis Play Games Pada Anak Usia Sekolah Dasar Rawamangun. Jurnal PJKR: UNJ

Eko, M J. 2018. Model Pembelajaran Gerak Dasar Manipulatif Berbasis Permainan Kecil untuk Anak Sekolah Dasar Kelas Atas. Jakarta: Jurnal Pascasarjana UNJ

Hadi, R F, Afriwardi, dan Yusri D J. 2015. Gambaran Obesitas pada Siswa Sekolah Dasar di SD Pertiwi dan SD Negeri 03 Alai Padang. Jurnal Kesehatan Andalas. 2015; 4(1)

Han Ahreum, Fu Allan, Cobley Stephen, Sanders Ross H. 2017. Effectiveness Of Exercise Intervention On Improving Fundamental Movement Skills And Motor Coordination In Overweight/Obese Children And Adolescents: A systematic Review.Journal of Science and Medicine in Sport http://dx.doi.org/10.1016/j.jsams.2017.07.001

Hendra, Jhony dan Ghazali I P. 2019. Mengembangkan Keterampilan Gerak Dasar Manipulatif bagi Anak melalui Permainan Olahraga di Taman Kanak-kanak. Jurnal Muara Pendidikan Vol.4 No.2.

Hidayat, Arif. 2017. Peningkatan Aktivitas Gerak Lokomotor, Nonlokomotor dan Manipulatif Menggunakan Model Permainan Pada Siswa Sekolah Dasar. Jurnal Pendidikan dan Jasmani Olahraga. Vol.2, No.2 September 2017

Julianur. 2017. Pengaruh Metode Permainan dan Intelligence Quotient (IQ) terhadap Kemampuan Gerak Dasar Manipulatif pada Siswa Pendidikan Anak Usia Dini (PAUD). JPES 6 (2).

Mahendra, Agus. 2017. Model Pendidikan Gerak (Movement Education) Dalam Pendidikan Jasmani. Modul. Bandung: FPOKUPI. 


\section{STRADA Jurnal Ilmiah Kesehatan}

DOI: $10.30994 /$ sjik.v9i2.294

ISSN: 2252-3847 (print); 2614-350X (online)

Vol.9 No.2 November 2020 Page.374-380

Mirawati dan Rahmawati, Eva. 2017.Permainan Modifikasi Untuk Stimulasi Keterampilan Gerak Dasar Manipulatif Anak Usia 2-4 Tahun. Jurnal Pendidikan : Early Childhood E-Issn. 2579-7190 Vol. 1 No. 2, November 2017.

Nugraha, L., Agus M., dan Indra H. 2018. Penerapan Model Pendidikan Gerak Dalam Pengembangan Pola Gerak Dasar Manipulatif Melalui Kerangka Analisis gerak (Movement Analysis Framework). Journal of Teaching Physical Education in Elementary School. Vol. 1, No.2.

Nugroho, DA, Agus K, dan Sapta KP. 2016. Meningkatkan Hasil Belajar Gerak Dasar Manipulatif Melempar dan Menangkap Bola melalui Media Visual pada Siswa SDLB-B (Tunarungu) SLB Negeri Sragen. Jurnal Media Ilmu Keolahragaan Indonesia. Vol 6, No.1 2016

Pradipta, GD. 2017. Strategi Peningkatan Keterampilan Gerak untuk Anak Usia Dini Taman Kanak-kanak B. Jendela Olahraga Vol. 2 No. 1, Januari 2017

Saputra, MW dan Kamal F. 2019. Hubungan Keterampilan Gerak Dasar Lokomotor dengan Hasil Belajar Penjasorkes. Jurnal Pendidikan dan olahraga: ISSN 2654-8887. Vol. 2 No. 8, Agustus 2019.

Sjarif DR. 2002. Obesitas pada Anak dan Permasalahannya. . Hot Topics in Pediatrics II. Jakarta: Balai Penerbit FKUI.

Sulistyani, Budi. 2016. Meningkatkan Kemampuan Gerak Manipulatif melalui Menggiring Bola pada Anak Kelompok A di TK ABA Tlegolelo Kokap Kulon Progo. Jurnal Pendidikan Anak Usia Dini. Edisi 9 Tahun Ke 52016.

Suryamulyawan, K.A., Arimbawa, I.M. 2019. Prevalensi dan karakteristik obesitas pada anak di Sekolah Dasar Saraswati V Kota Denpasar tahun 2016. Intisari Sains Medis 10(2): 342-346. DOI: 10.15562/ism.v10i2.393.

Suyantini, Iis. 2013. Peningkatan Keterampilan Gerak Manipulatif melalui Permainan Bola Beranting Anak Usia 5-6 Tahun. Universitas Tanjungpura: Pontianak.

Yasin, M. 2018. Pengaruh Modifikasi Permainaan Menedang Bola Terhadap Koordinasi Gerak Manipulatif Anak Tunagrahita Siswa Slb-C Ypplb Cendrawasih Makassar. Jurnal IKOR. UNM 